\title{
PKM PEMANFAATAN KOTORAN KELINCI \\ PADA KELOMPOK TANI TERNAK DI KAWASAN WISATA \\ DESA PANCASARI-KECAMATAN SUKASADA KABUPATEN BULELENG, PROVINSI BALI
}

Anak Agung Ngurah Mayun Wirajaya ${ }^{1)}$; Made Sri Yuliartini ${ }^{2)}$; I Dewa Nyoman Sudita ${ }^{3)}$ mawir61@gmail.com /yuliartinisri@yahoo.co.id./idnsudita@gmail.com

\begin{abstract}
ABSTRAK
Kegiatan PKM ini dilaksanakan pada Kelompok Tani Ternak "Wana Sari Merta” di Desa Pancasari, Kecamatan Sukasada-Kabupaten Buleleng, Provinsi Bali dengan judul "PKM Pemanfaatan Kotoran Kelinci Pada Kelompok Tani Ternak Di Kawasan Wisata Desa Pancasari-Kecamatan Sukasada, Kabupaten Buleleng Provinsi Bali”. Sampai saat ini di Desa Pancasari yang berada disekitar lokasi wisata Danau Buyan dan Danau Tamblingan masyarakatnya dalam budidaya tanaman yang banyak dikembangkan tanaman cabai, tomat, sawi, kentang, brokoli, selada, wortel, stroberi dan jenis lainnya dan masih banyak menggunakan pupuk organik yang berasal dari kotoran ayam yang mudah didapat dalam jumlah besar dan dapat memenuhi kebutuhan luasan tanam yang cukup luas. Kesempatan ini sebenarnya dapat dimanfaatkan oleh masyarakat petani ternak khususnya kelinci sebagai peluang untuk mensuplai pupuk organik dari limbah kelinci baik padat maupun cair.

Sampai saat ini permasalahan yang dihadapi mitra adalah kotoran padat dan cair belum diolah secara optimal dan memproses /memproduksi pupuk organik dari kotoran tersebut belum secara intensif/hanya sewaktu-waktu sesuai permintaan, produk belum dikemas dengan baik dan belum ada label sehingga dalam proses pemasaran belum dapat dikenal secara luas asal produsennya yang menjadi kendala bagi kelompok mitra, aspek manajemen dan pemasaran produk serta faktor penunjang lainnya masih perlu ditingkatkan. Solusi yang sudah diberikan pada kelompok mitra adalah transfer teknologi budidaya kelinci penyiapan pakan fermentasi, teknologi pengolahan kotoran kelinci, uji mutu produk pada laboratorium, kemasan dan pelabelan, manajemen usaha, pemasaran, temu usaha/mitra, serta bantuan alat dan bahan.

Tujuan kegiatan PKM ini bagi mitra adalah: adanya peningkatan pengetahuan dan keterampilan mitra dalam budidaya kelinci serta memanfaatkan limbah padat dan cair kelinci sebagai pupuk organik dalam mensubstitusi penggunaan pupuk anorganik yang ada di wilayah mitra. Selain itu, dapat menjadi alternatif bahwa limbah padat dan cair kelinci bagi masyarakat disekitar mitra dapat dipakai sebagai pupuk organik dalam pemupukan tanaman
\end{abstract}


yang dibudidayakan selain pupuk-pupuk organik dari ayam yang telah digunakan saat ini . Sentuhan teknologi dalam pengolahan limbah kelinci akan memberi nilai tambah yang tinggi bagi petani ternak mitra. Dari kegiatan ini target luaran yang telah dicapai yaitu kelompok mitra secara mandiri mampu memanfaatkan limbah kelinci padat maupun cair dengan baik menjadi "Pupuk Organik Padat" (POP) dan "Pupuk Organik Cair" (POC) yang dikemas dan ada label sehingga dapat dipasarkan lebih luas dan diharapkan dapat meningkatkan pendapatan kelompok mitra.

\section{Kata Kunci: Petani/Peternak, kelinci, pengemasan, pupuk organik.}

${ }^{1)}{ }^{2)}$, : Dosen PS.Agroteknologi -Fakultas Pertanian Universitas Warmadewa

3) : Dosen PS.Peternakan -Fakultas Pertanian Universitas Warmadewa

\section{PENDAHULUAN}

\section{Analisis Situasi}

Desa Pancasari terletak di Kecamatan Sukasada yang berada di bagian paling selatan Kabupaten Buleleng merupakan salah satu dari desa dengan luas wilayah 12,80 $\mathrm{km}^{2}$ dan merupakan daerah perbukitan dengan ketinggian $1.250 \mathrm{~m}$ dari permukaan laut. Jarak dari ibukota Provinsi Bali Denpasar 59,0 km. Adapun batas-batas wilayahnya adalah:

$$
\begin{array}{ll}
\text { Sebelah Utara } & \begin{array}{l}
\text { : Desa Wanagiri- } \\
\text { Kecamatan Sukasada }
\end{array} \\
\text { Sebelah Timur } & \text { : Hutan Negara } \\
\text { Sebelah Selatan : Desa Candikuning- }
\end{array}
$$$$
\text { Kecamatan Baturiti }
$$

Sebelah Barat : Hutan Negara

Secara administrasi Desa Pancasari terdiri dari 5 (lima) banjar dinas yaitu: 1). Banjar Dinas Buyan, 2). Banjar Dinas Peken, 3).
Banjar Dinas Dasong, 4). Banjar Dinas Karma, 5). Banjar Dinas Lalang Linggah [Profil Desa Pancasari, 2017].

Desa Pancasari yang terletak di dekat dua danau yaitu Danau Buyan dan Danau Tamblingan, sebagian besar masyarakatnya menggantungkan hidupnya pada sektor pertanian, peternakan, perkebunan. Di sektor pertanian, komoditas yang dikembangkan oleh petani sebagian besar berupa tanaman hortikultura yang tumbuh dan berkembang dengan baik sangat didukung oleh iklim disekitarnya. Sebagian besar petani menanam tanaman hortikultura berupa cabai, tomat, sawi, kentang, brokoli, selada, wortel, stroberi dan lainnya. Sebagian besar produk hasil pertanian petani dijual untuk kepentingan pemenuhan kebutuhan pariwisata selain 
dijual kepasar-pasar tradisional yang ada diseluruh Bali.

Produk pertanian yang dihasilkan oleh petani agar dapat mempunyai kualitas dan kuantitas yang sesuai dengan kebutuhan pasar dan agar kesuburan tanah tetap memberi dukungan pada produk yang dihasilkan dibutuhkan pupuk. Petani dalam pemupukan masih mempergunakan pupuk organik dan an organik dalam budidaya tanaman hortikulturanya. Sampai saat ini petani masih dominan menggunakan pupuk organik berupa pupuk kandang ayam dalam pemenuhan luasan penanaman yang cukup luas yang sebagian besar dibeli dari luar daerah Pancasari..

Memperhatikan masih banyaknya potensi limbah dari hewan yang dapat dipakai sebagai pupuk organik dan cukup besarnya kebutuhan akan pupuk organik, maka kelinci yang cukup banyak dipelihara oleh petani ternak kelinci di Pancasari menjadi salah satu alternatif pemenuhan kebutuhan pupuk organik dari limbah kelinci sangat terbuka lebar. Tercatat peternak kelinci sebanyak 112 orang dengan jumlah kelinci 1.500 ekor (Profil Desa Pancasari, 2017). Walaupun keberadaan kelinci dan kotorannya cukup tersedia, namun masih kurang mendapat perhatian dari petani untuk memanfaatkannya sebagai sumber pupuk organik.

Kandungan unsur hara dari limbah kotoran kelinci lebih baik dari beberapa pupuk organik/pupuk kandang lainnya sebenarnya memberi harapan bagi petani untuk mengelola kelinci dengan baik dan memanfaatkan kotorannya semaksimal mungkin guna meningkatkan produksi tanaman. Pupuk organik cair yang berasal dari urin kelinci mempunyai kandungan unsur hara yang cukup tinggi yaitu $\mathrm{N} 4 \%$, $\mathrm{P}_{2} \mathrm{O}_{5} 2,8 \%$, dan $\mathrm{K}_{2} \mathrm{O}$ 1,2\% relatif lebih tinggi daripada kandungan unsur hara pada sapi ( $\mathrm{N} 1,21 \%, \mathrm{P}_{2} \mathrm{O}_{5}$ 0,65\%, dan $\mathrm{K}_{2} \mathrm{O}$ $1,6 \%)$ dan kambing ( $\mathrm{N} 1,47 \%, \mathrm{P}_{2} \mathrm{O}_{5}$ 0,05\%, dan $\mathrm{K}_{2} \mathrm{O} 1,96 \%$ ) (Sembiring, $d k k$, 2017). Dari hasil penelitian Karo, $d k k$., (2014) menyebutkan bahwa teknik penanaman dengan menggunakan plastik mulsa warna perak di atas dan teknik pemberian urine kelinci dengan disiram dapat meningkatkan produksi kentang, khususnya persentase kentang grade besar $(47,21 \%)$. Selain urin kelinci, disebutkan oleh Erika dan Paiman , (2011) kandungan feses kelinci dimana satu ekor kelinci yang berusia dua bulan lebih, atau yang beratnya sudah mencapai $1 \mathrm{~kg}$ akan menghasilkan 28,0 g kotoran lunak per hari dan mengandung $3 \mathrm{~g}$ protein serta $0,35 \mathrm{~g}$ nitrogen dari bakteri atau setara 1,3 g protein. Pemakaian pupuk organik perlu 
ditingkatkan dan mendapat prioritas tidak hanya untuk meningkatkan kesuburan tanah, tetapi juga untuk membantu menciptakan agroekosistem yang berkesinambungan dan aman bagi kesehatan manusia (Zulkarnain, 2009). Hasil pemanfaatan kotoran kelinci pada tanaan kentang dan kubis rata-rata meningkatkan produksi sebesar 23,5\% dibandingkan pupuk domba (Sajimin, $d k k ., 2005)$. Hasil penelitian Ruminta $d k k$, (2017) pada pemberian perlakuan pupuk kandang kelinci 5 ton/ha memberikan pengaruh mandiri yang terbaik terhadap panjang malai, bobot malai per rumpun dan bobot biji per tanaman. Sedangkan perlakuan pupuk kandang 5 ton/ha + urin kelinci 7,5 ml/tanaman memberikan pengaruh mandiri yang terbaik terhadap rendemen kerontokan.

Pelaksanaan Program Kemitraan Masyarakat (PKM) akan bermitra dengan 1 (satu) kelompok tani ternak yang memiliki kemauan kuat untuk maju dan mengelola usahanya dengan baik yaitu kelompok "WANA SARI MERTA" yang terdiri dari 5 anggota dan diketuai oleh Kadek Sutama dengan jumlah kelinci dipelihara sebanyak 60 ekor dengan kandang yang sederhana. Program ini akan diarahkan pada usaha pemeliharaan dan pemanfaatan kotoran kelinci dengan baik, pengemasan dan labeling produk, serta usaha/bisnis kotoran kelinci dalam bentuk "Pupuk Organik Padat" dan "Pupuk Organik Cair".

Anggota kelompok tani ternak mitra, sebagian besar menjalankan usaha dengan beternak dan bertani tanaman hortikultura. Dari usaha yang dijalankan diberbagai bidang diharapkan dapat membantu keluarga dalam peningkatan pendapatannya. Memanfaatkan kotoran kelinci yang sebelumnya tidak dipandang merupakan pekerjaan mengisi waktu yang menguntungkan. Diharapkan dengan adanya pengabdian kepada masyarakat yang didanai oleh Ristekdikti, masyarakat Desa Pancasari di kelompok tani ternak "Wana Sari Merta" akan mengalami perubahan dibidang budidaya tanaman dan mengolah sumberdaya alam terutama kelinci serta kotoran nya.

Berdasarkan hasil observasi dilapang dapat diperoleh informasi permasalahan yang dihadapi mitra yaitu kotoran padat dan cair belum diolah secara optimal dan memproses /memproduksi pupuk organik dari kotoran tersebut belum secara intensif/hanya sewaktu-waktu sesuai permintaan, produk belum dikemas dengan baik dan belum ada label sehingga dalam proses pemasaran belum dapat dikenal secara luas asal produsennya yang menjadi kendala bagi kelompok mitra, aspek manajemen 
kelembagaan kelompok dan pemasaran produk serta faktor penunjang lainnya masih perlu ditingkatkan. Oleh karena itu kelompok mitra perlu difasilitasi dari aspek teknologi pengolahan kotoran kelinci, uji mutu produk pada laboratorium, kemasan dan pelabelan, manajemen usaha, pemasaran.

Transfer teknologi dalam budidaya dan pengolahan kotoran kelinci akan memberi nilai tambah yang tinggi bagi petani ternak mitra utamanya dari mutu kotoran dan peningkatan pendapatan petani.
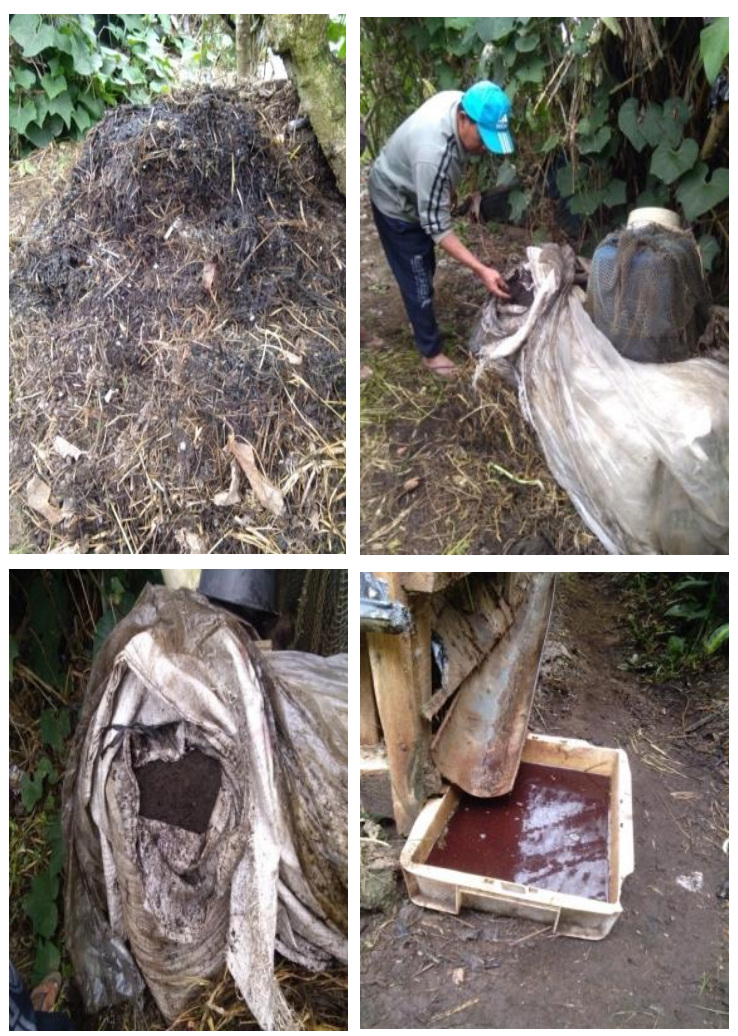

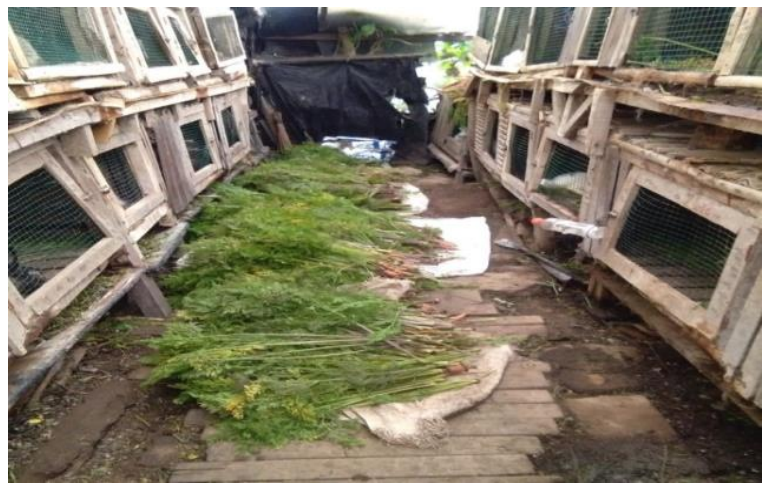

Gambaran Umum Kondisi Mitra

\section{Tujuan kegiatan:}

1. Adanya peningkatan pengetahuan dan keterampilan mitra dalam budidaya kelinci serta memanfaatkan kotoran padat dan cair menjadi POP dan POC kelinci sebagai pupuk organik dalam mensubstitusi penggunaan pupuk anorganik yang ada di wilayah mitra.

2. Meningkatkan pemahaman teknologi pengolahan limbah ternak kelinci menjadi pupuk dan mampu membuat/memproduksi pupuk organik padat dan cair yang berkualitas dan bernilai ekonomi tinggi bagi kelompok mitra.

3. Meningkatkan kesejahteraan masyarakat petani peternak dengan nilai tambah dari hasil olahan yang bermutu dari kotoran kelinci.

4. Meningkatkan keinginan masyarakat di desa Pancasari untuk memanfaatkan kotoran padat dan cair kelinci sebagai pupuk pada tanaman yang dibudidayakan. 
5. Meningkatkan jaringan pemasaran produk Pupuk Organik Padat dan Pupuk Organik Cair kelinci lebih luas.

6. Kelompok mitra memiliki kemampuan manajemen usaha yang lebih baik.

\section{Manfaat Kegiatan}

1. Bagi anggota kelompok agar dapat meningkat kemampuannya dalam budidaya kelinci dan pengolahan kotoran kelinci menjadi produk yang bernilai ekonomi dan meningkatkan kesejahteraan petani/peternak serta kemandirian kelompok.

2. Bagi masyarakat sekitar lokasi kegiatan/ Desa Pancasari agar lebih banyak menggunakan pupuk organic padat dan pupuk organic cair dari kotoran kelinci sebagai sumber pupuk pada tanaman yang dibudidayakannya.

3. Masyarakat diluar Desa Pancasari untuk memanfaatkan pupuk organic padat dan pupuk organic cair baik untuk kebutuhan individu maupun sebagai bagian kegiatan bisnisnya.

4. Lembaga Perguruan Tinggi diharapkan kegiatan ini dipakai sebagai model pemberdayaan masyarakat dan dapat dipakai sebagai tempat pengembangan penelitian-penelitian.

5. Pemerintah diharapkan kegiatan ini dapat dipakai sebagai upaya pemberdayaan masyarakat dan menjadi model pengembangan dalam peningkatan kesejahteraan masyarakat.

\section{Tempat dan Waktu Pelaksanaan}

Pelaksanaan

pengabdian masyarakat diselenggarakan di Kelompok Tani Ternak "Wana Sari Merta" di Desa Pancasari Kecamatan Sukasada, Kabupaten Buleleng-Provinsi Bali. Waktu pelaksanaan dimulai saat proposal PKM ini disetujui oleh Dikti pada awal tahun 2020 dan berlangsung sampai akhir tahun 2020.

\section{Metode Pendekatan}

Metode pelaksanaan program PKM kelompok tani ternak dilakukan dengan kegiatan sosialisasi, pendampingan, pelatihan dan transfer teknologi. Pendampingan dilakukan terhadap 5 anggota kelompok tani. Jenis kegiatan yang dilakukan sebagai berikut: (1). Sosialisasi program PKM, (2). Penyuluhan dan pelatihan, (3). Pengenalan dan transfer teknologi pembuatan POP \& POC, (4). Pengenalan dan transfer teknologi pembuatan kemasan dan labeling, (5). Penguatan kelembagaan, manajemen usaha dan pemasaran..

Secara rinci kegiatan dilakukan dengan:

1. Penyuluhan kepada anggota kelompok terlebih dahulu diberikan materi utama 
berupa materi budidaya kelinci, pembuatan pakan fermentasi, teknologi pengolahan limbah ternak menjadi produk pupuk organik padat dan cair, pengemasan dan labeling, dan materi penunjang lainnya mengenai manajemen usaha, pemasaran serta upaya peningkatan hasil tanaman.

2. Penyerahan alat-alat dan bahan-bahan kepada peserta didik, yang bisa dipakai sebagai sarana pelaksanaan untuk meningkatkan penerapan teknologi pemanfaatan \& pengolahan kotoran kelinci, kontinu dan kualitas pupuk kelinci serta peningkatan hasil saat panen.

3. Pelaksanaan praktek guna mendapatkan bukti bahwa kotoran kelinci sangat baik untuk pertumbuhan, perkembangan serta produksi tanaman hortikultura dengan baik dapat dilakukan dengan beberapa cara yaitu: a).Pembuatan pakan ternak fermentasi guna dapat diberikan kepada kelinci saat sulit mendapatkan pakan dari lingkungan sekitarnya akibat perubahan iklim dan mendapat kotoran yang bermutu, b). Pembuatan Pupuk Organik Cair (POP) dan Pupuk Organik Cair (POC) fermentasi, c). Cara pengemasan dan labeling.

4. Monitoring dan Pendampingan: pihak pengusul kegiatan akan melakukan monitoring dan pendampingan secara berkala untuk memastikan keberhasilan usaha yang akan dikembangkan oleh mitra. Pada tahap ini, akan dilakukan analisis terhadap kemungkinan permasalahan yang muncul dari pihak mitra selama menjalani usaha serta mengupayakan solusinya.

5. Evaluasi akhir akan dilakukan terhadap materi pengabdian yang diberikan dan diterapkan oleh petani ternak dari pemeliharaan dan pemanfaatan kotoran kelinci, pemanfaatannya di tanaman hortikultura dan pemasaran nya sehingga dapat meningkatkan pendapatan petani ternak kelinci.

\section{HASIL DAN PEMBAHASAN}

Dalam menjalankan program PKM Universitas Warmadewa sebagai salah satu perguruan tinggi selalu menjalankan Tridharma dengan kegiatan pengabdian kepada masyarakat akan mendorong civitas akademika untuk membantu masyarakat khususnya pada kelompok tani ternak di Desa Pancasari.

Dari permasalahan yang dihadapi oleh kelompok tani ternak "Wana Sari Merta" maka melalui proses diskusi, penyuluhan, praktek langsung, pendampingan beberapa solusi yang telah dilaksanakan dan berhasil adalah: 


\section{Penyampaian Materi saat Penyuluhan}

Dalam menjalankan kegiatan di kelompok dapat berjalan dengan baik, maka sumber daya manusia haruslah diberi peningkatan kemampuan masing-masing melalui tatap muka penyuluhan. Anggota telah megikuti kegiatan penyuluhan dengan tertib dan disiplin. Materi yang diberikan menyangkut beberapa hal yang mendukung keberhasilan program pengabdian ini antara lain budidaya kelinci, teknologi pembuatan POP dan POC kelinci, pengemasan dan labeling, manajemen usaha dan pemasaran produk.

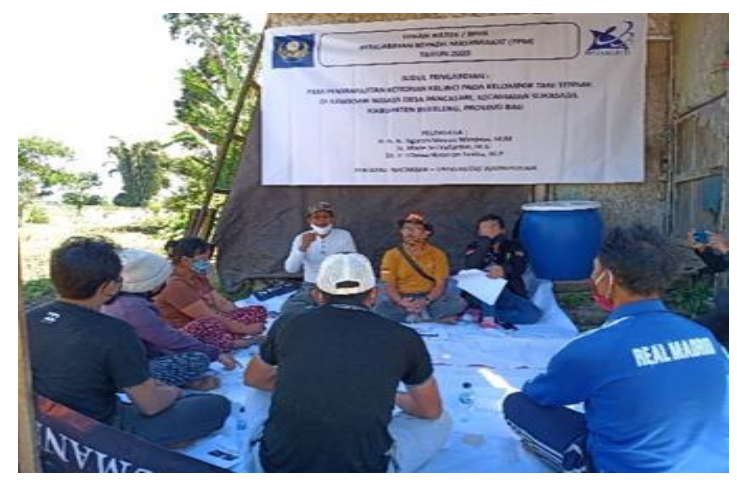

Kelompok "Wana Sari Merta" saat penyuluhan

\section{Transfer Teknologi Pembuatan}

\section{Pakan Fermentasi}

Kualitas, kuantitas dan kontinuitas makan merupakan salah satu kunci keberhasilan dalam budidaya kelinci.
Pada kelompok tani Wana Sari Merta pada musim kemarau ketersediaan makanan sering menjadi masalah. Telah dilakukan pemberian makanan yang bersumber dari tanaman jenis pakan konvensional berupa rumput yang tumbuh di sekitar tempat usaha dan jenis sayuran lain namun masih banyak sisa yang sebenarnya kalau dilakukan sedikit inovasi teknologi terhadap pakan akan dapat dimanfaatkan secara total. Saat musim kemarau sering dijumpai pakan konvensional berupa rumput lokal yang menjadi makanan andalan ketersediaannya sangat terbatas , selalu dicoba dan tetap melakukan inovasi untuk mendapatkan sumber makanan yang bermutu.

Program transfer teknologi khususnya penyediaan pakan yang diberikan setiap harinya agar dapat tersedianya pakan kelinci dimana saat musim kemarau sulit mendapatkan sumber pakan, salah satu upaya dengan membuat pakan fermentasi yang dapat tersedia cukup lama dengan jumlah yang cukup banyak dari sumber bahan pakan selain rumput, sayur-sayuran, dedak, molase,EM 4 dan sedikit garam.

Dengan penyediaan pakan fermentasi petani peternak mendapatkan 1].Seluruh bagian pakan yang dulu hanya dimakan daunnya saja, tapi dengan di fermentasi akan semua dapat digunakan, 
2].Kualitas pakan akan lebih baik karena ada tambahan dari bahan dedak, molase, EM 4 dan garam, 3]. Stok pakan dapat tersedia dalam jangka waktu cukup lama.

Penyediaan pakan yang bermutu diharapkan memberi dampak pada kotoran padat dan cair kelinci semakin meningkat mutunya dan telah dilaksanakan dengan baik oleh peternak.

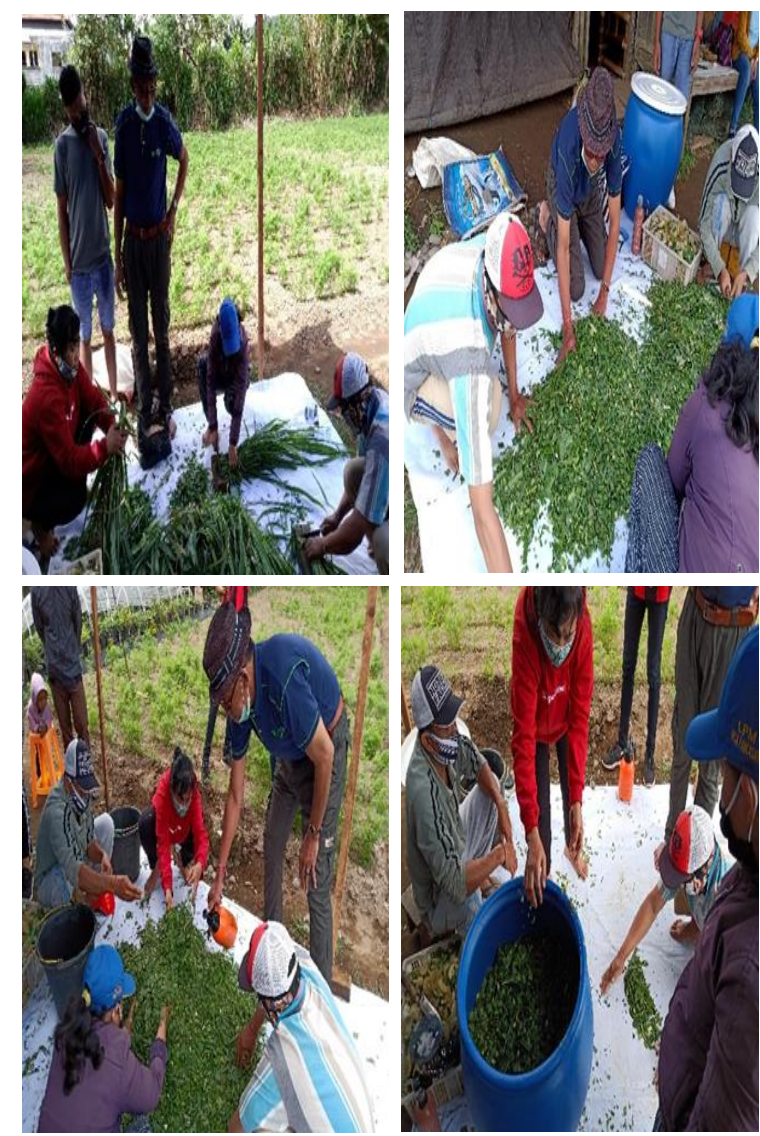

Praktek Pembuatan Pakan Fermentasi

\section{Transfer Teknologi Proses}

\section{Pengolahan Kotoran Kelinci}

Pupuk organik padat/POP dan pupuk organik cair/POC yang dihasilkan oleh mitra kualitas produknya masih rendah. Dalam menjalankan kegiatan https://ejournal.warmadewa.ac.id/index.php/wicaksana

budidaya kelinci sumber daya manusia memegang peranan yang sangat penting. Kotoran kelinci yang menjadi bagian dari budidaya kelinci dapat memberi manfaat bila dikelola dengan baik sebagai pupuk dan itu terwujud bila kemampuan sumberdaya manusia yang melakukan kegiatannya memadai untuk mengolahnya dengan benar. Kotoran kelinci yang telah ada di kelompok ini cukup banyak namun perlu ditingkatkan kualitasnya dengan memberi penyuluhan, pelatihan dan pendampingan sehingga dapat menjadi hasil tambahan selain kelinci yang dijual sebagai sumber penghasilan yang utama. Ini telah dilakukan melalui pemberian materi penyuluhan, pelatihan dan pendampingan di lapang. Telah didapat bahwa petani paham dan mau untuk memanfaatkan kotoran kelinci untuk ditingkatkan mutunya dengan pemberian bahan-bahan tambahan untuk fermentasi. Sentuhan teknologi melalui pelatihan dan bimbingan teknis proses fermentasi dan pemberian EM 4, molase/gula merah, dan tambahan lainnya akan menjadikan produk limbah padat dan cair kelinci akan lebih bermutu. Untuk pupuk organic cair 

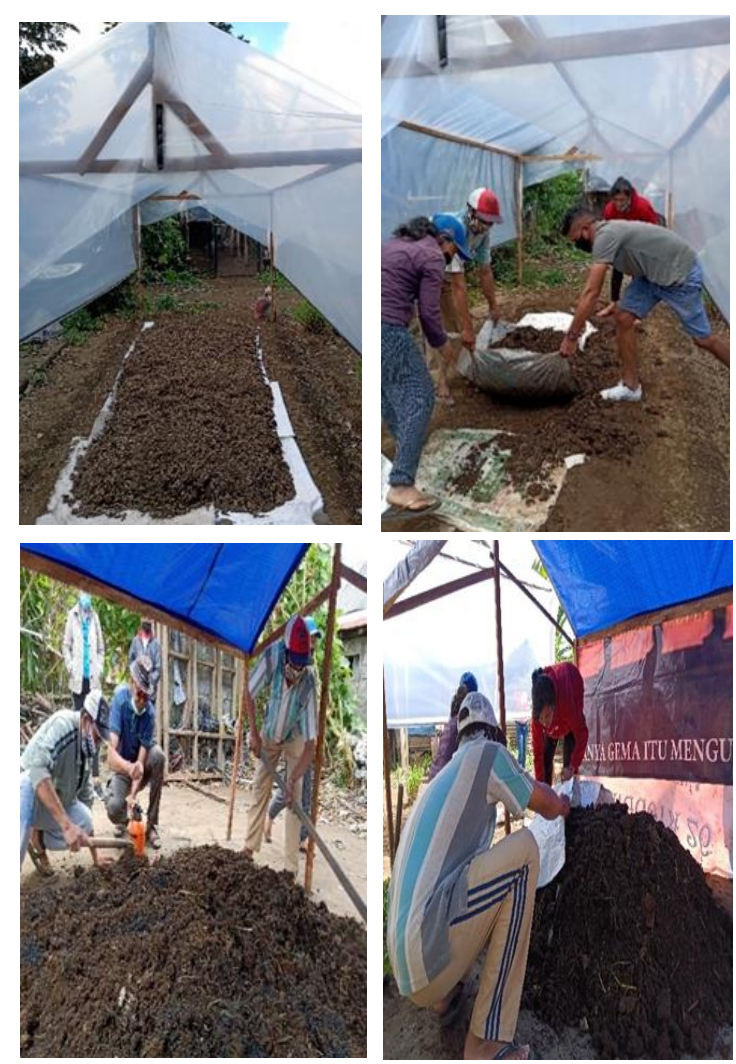

Proses Pengolahan Kotoran Padat dan Fermentasi
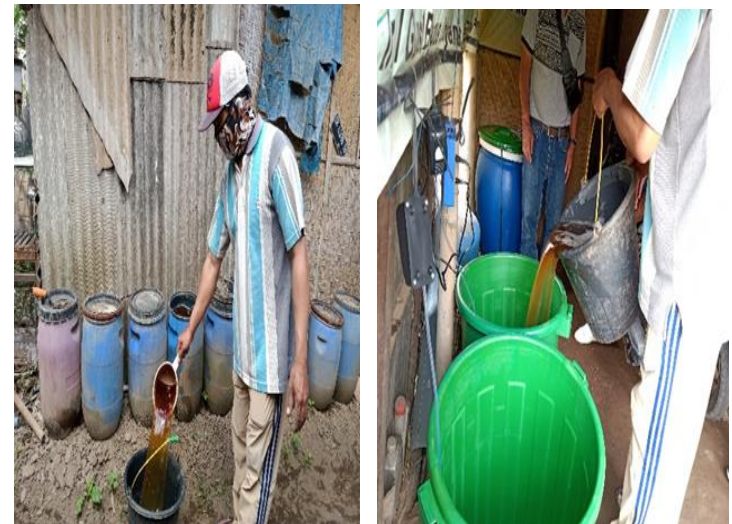

Proses Pengolahan Kotoran Cair dan Fermentasi

\section{Pengujian POP\& POC, Labeling dan Pengemasan}

Sebagai produk olahan kotoran kelinci berupa POP \& POC yang sudah difermentasi dari kelompok tani agar lebih meyakinkan konsumen, maka dilakukan uji laboratorium sehingga akan dapat diketahui kandungan unsur hara pada produk. Telah dilakukan uji laboratorium dan hasilnya telah dicantumkan pada labeling kemasan POP \& POC. Agar anggota kelompok dapat mengemas dengan baik dilakukan proses pelatihan menggunakan alat pengemas mesin untuk POP dan POC dengan menyiapkan botol plastic beberapa ukuran disesuaikan dengan kebutuhan pasar. Anggota kelompok telah mampu melakukan pengemasan dengan baik dan merasakan manfaat dari pengemasan untuk memudahkan pemasaran. Bentuk, besar kemasan, design pada kemasan menjadi perhatian agar menarik konsumen. Diharapkan dengan ketersediaan kemasan yang sudah memadai akan dapat menembus pasar di luar Desa Pancasari.
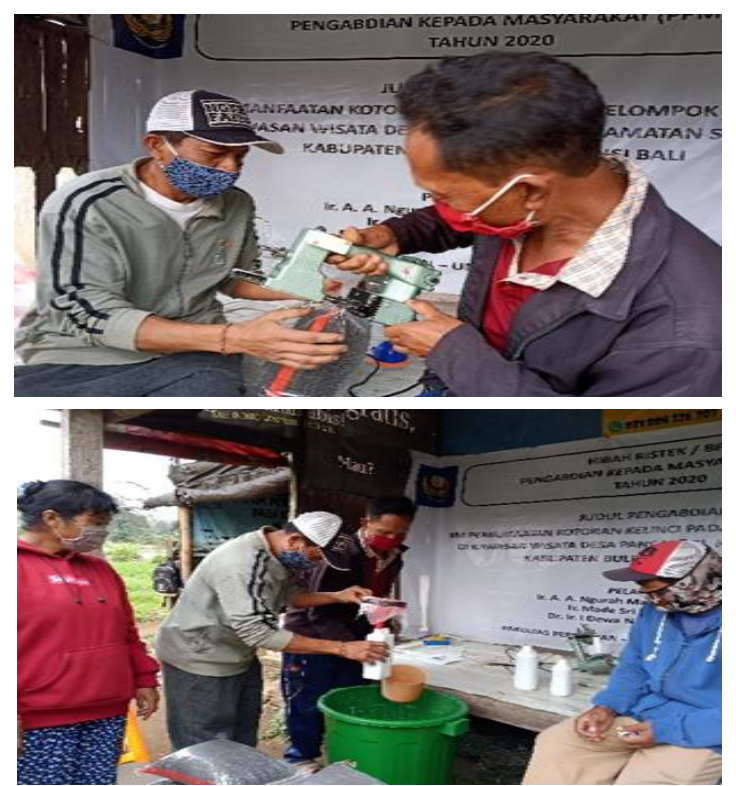

Latihan Pengemasan POP \& POC 

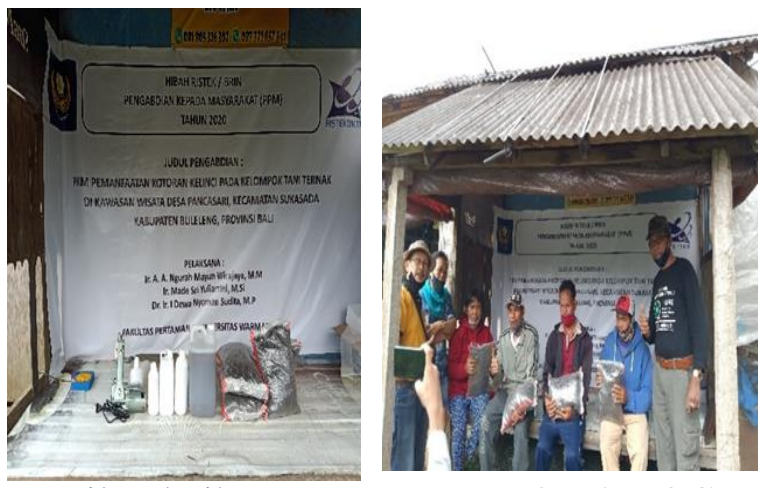

Hasil Pelatihan Pengemasan POP \& POC

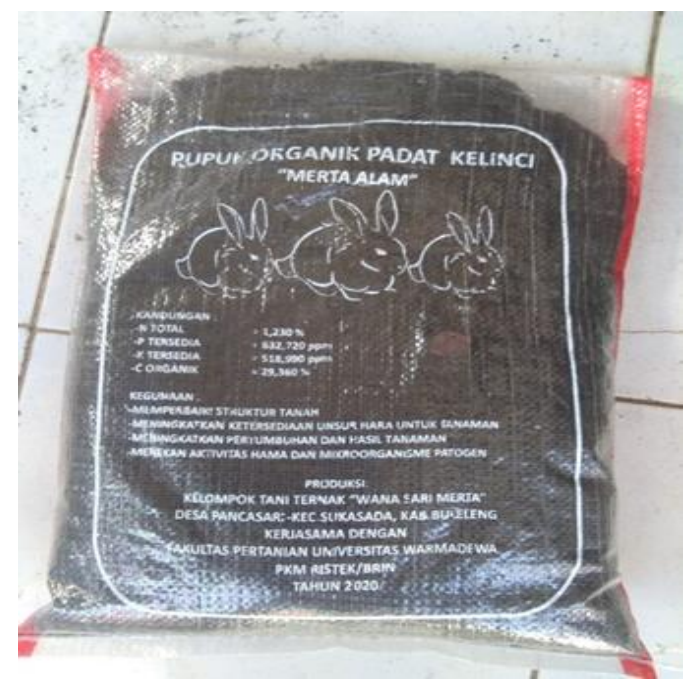

Labeling dan Kemasan POP

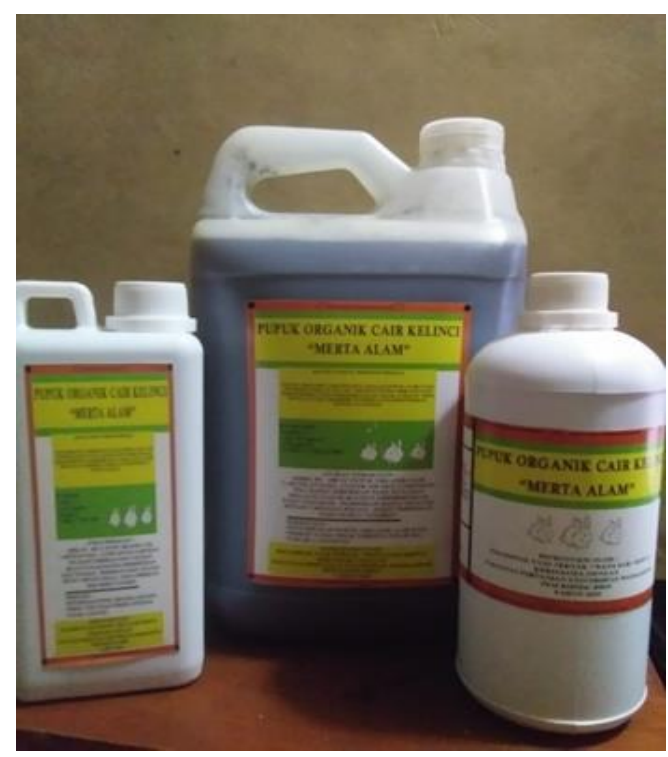

Labeling dan Kemasan POC

\section{Sosialisasi dan Pemasaran}

Bila ingin produknya dikenal dan diminati oleh banyak orang diperlukan perluasan jaringan dengan sosialisasi produk melalui kegiatan temu usaha atau mitra baik dengan pengusaha/mitra maupun pengguna/petani yang ada disekitar lokasi kegiatan maupun dari luar daerah. Sosialisasi telah difasilitasi dan dilaksanakan dengan mendapat respon positif dari peserta temu usaha. Semakin luas dikenal melalui sosialisasi dan pemberitaan melalui media cetak dan elektronik akan memperluas jaringan pemasaran. Respon dari pengguna dari luar daerah setelah sosialisasi melalui temu usaha/mitra menjadikan POP \& POC semakin prospektif untuk dikembangkan dan ditingkatkan mutunya. Target temu usaha sudah terlaksana dengan baik.

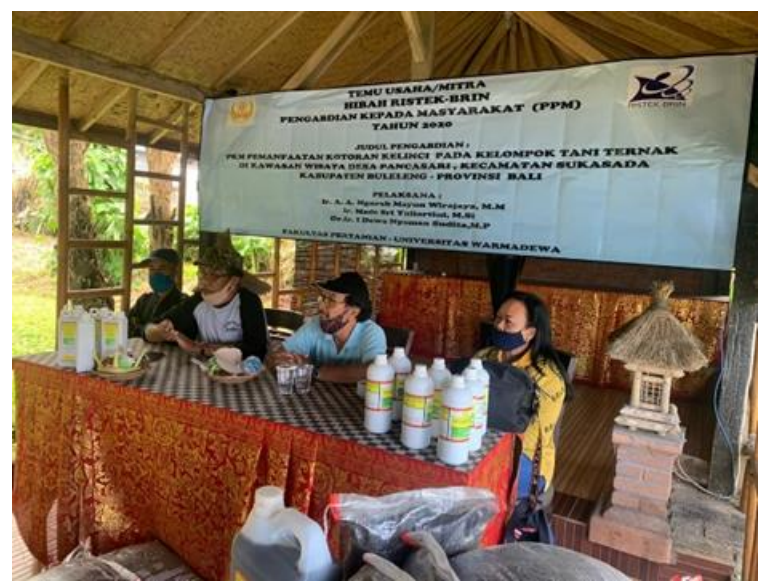



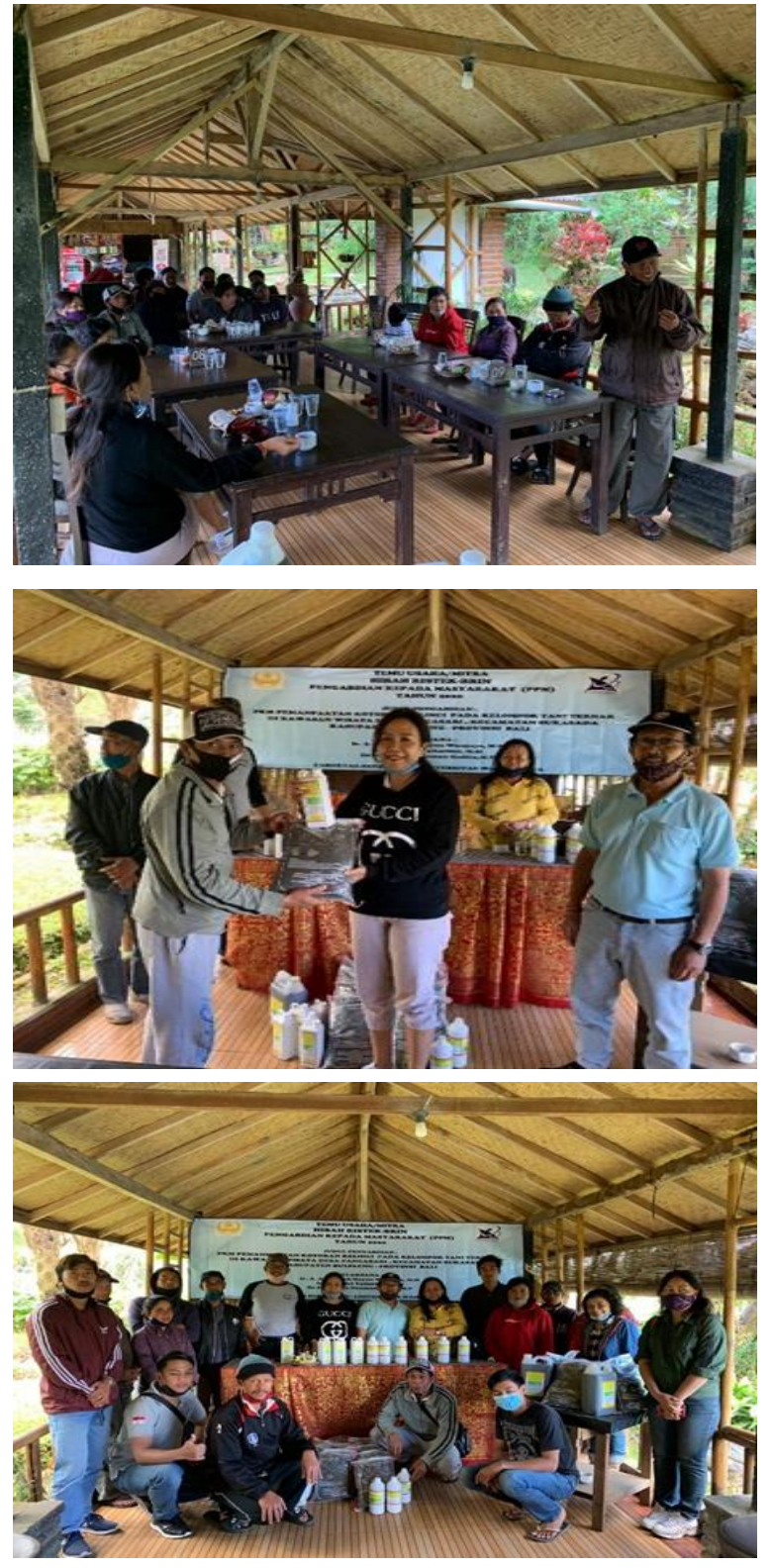

\section{Dokumentasi Sosialisasi melalui Temu Usaha/Mitra di Pancasari}

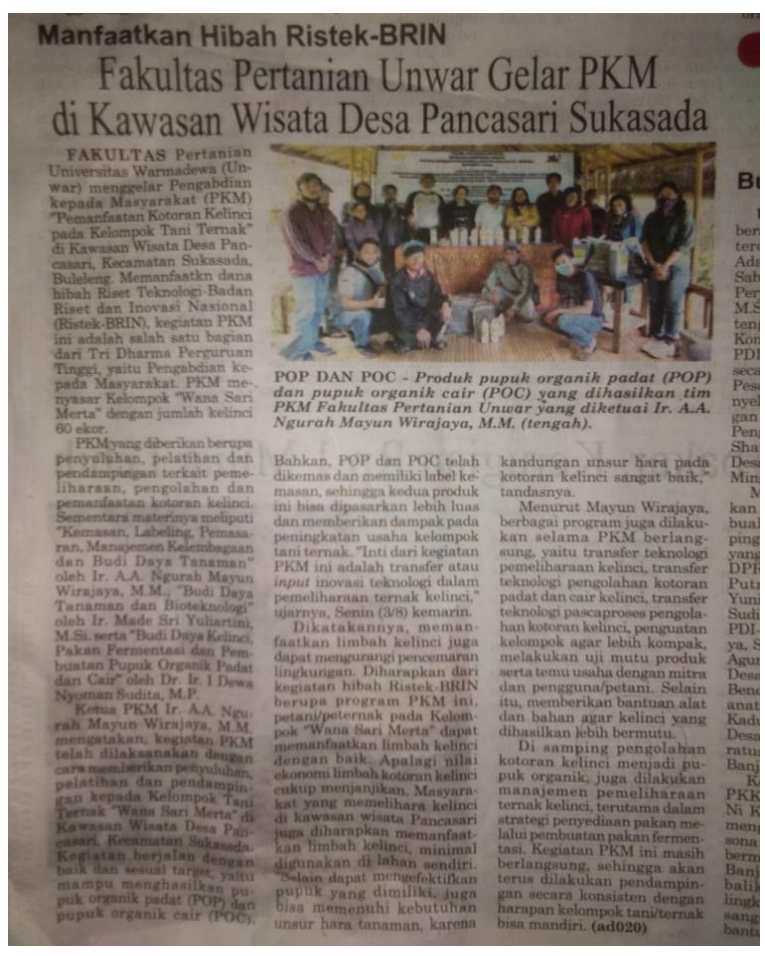

Publikasi di Media Cetak Bali Post

\section{KESIMPULAN}

Kelompok mitra tani ternak "Wana Sari Merta" di Desa Pancasari dalam PKM ini telah mampu mengadopsi segala materi yang diberikan. Hal tersebut dapat ditunjukkan antara lain:

1. Anggota mitra telah menunjukkan adanya kesungguhan mengikuti penyuluhan, berinteraksi saat penyuluhan, praktek dilapang, pendampingan.

2. Dapat dibuatnya pakan fermentasi oleh anggota mitra dalam mengantisipasi kekurangan pakan saat kemarau panjang.

3. Kotoran kelinci sebagai bahan pupuk organik padat dan pupuk organik cair 
dapat disiapkan untuk diolah pada bangunan fermentasi representatif.

4. Telah didapat Pupuk Organik Padat dan Pupuk Organik Cair yang siap dipasarkan setelah proses fermentasi.

5. Pupuk Organik Padat dan Pupuk Organik Cair yang sudah difermentasi telah dilakukan uji laboratorium untuk mengetahui kandungan unsur makronya.

6. Pupuk Organik Padat dan Pupuk Organik Cair agar mudah dipasarkan sudah dikemas dengan baik dan telah ada labeling.

7. Manajemen organisasi telah dipahami untuk dapat berjalannya kelompok lebih baik.

8. Temu usaha/mitra telah dapat berlangsung dengan baik dalam rangka sosialisasi produk dan meningkatkan jaringan pemasaran. Media Cetak dan elektronik telah dapat meningkatkan peningkatan pesanan POP \& POC.

9. Telah diberikan bantuan alat dan bahan untuk mendukung kegiatan usaha untuk mendapatkan kualitas, kuantitas dan kontinu produk olahan.

\section{Saran}

Kotoran kelinci yang cukup tinggi kandungan unsur hara makro sangatlah besar manfaatnya bagi tanaman. Beberapa hal yang kami sarankan adalah: a. Bangunan penampung dan fermentasi kotoran kelinci agar dibuat lebih representatif untuk mendapatkan bahan baku dan produk pupuk organik padat lebih baik.

b. Perlu dibuatkan kandang yang lebih baik agar kotoran padat dan cair kelinci dapat tertampung secara maksimal.

\section{REFERENSI}

(1).Profil Desa Pancasari, 2017. Profil Desa dan Kelurahan, Desa Pancasari, Kecamatan Sukasada, Kabupaten Buleleng-Provinsi Bali.

(2).Sembiring, Melda Yuartaria; Lilik Setyobudi; Yogi Sugito, 2017. Pengaruh Dosis Pupuk Urin Kelinci Terhadap Pertumbuhan dan Hasil Beberapa Varietas Tomat. Jurnal Produksi Tanaman, Vol. 5 No.1, Januari 2017: 132-139, ISSN; 25278452. Universitas Brawijaya-Malang.

(3).Karo, Bina Br.; Agustina E Marpaung; dan Agung Lasmono, 2014. Efek Tehnik Penanamandan Pemberian Urin Kelinci Terhadap Pertumbuhan dan Produksi Tanaman Kentang Granola (Solanum tuberosum L).Prosiding Seminar Nasional Sains dan Inovasi Teknologi Pertanian.

(4).Erika Dewi Nugraheni dan Paiman, 2011. Budidaya Tanaman Cabai 
Merah. Surakarta, Universitas Sebelas Maret

(5).Zulkarnain, H. 2009. Dasar-dasar Hortikultura. Penerbit PT. Bumi Aksara-Jakarta. REFERENSI

(6).Sajimin, Yono C.Rahardjo, Nurhayati D.Purwantari , 2005. Potensi Kotoran Kelinci Sebagai Pupuk Organik dan Pemanfaatannya Pada Tanaman Pakan dan Sayuran. Lokakarya Nasional Potensi dan Peluang Pengembangan Usaha Agribisnis Kelinci. Balai Penelitian Ternak - Bogor.

(7).Ruminta, A.Wahyudin, M.L.Hanifa, 2017. Pengaruh Pupuk N,P,K dan Pupuk Organik Kelinci Terhadap Hasil Sorgum (Sorghum bicolor [Linn] Moench) di Lahan Tadah Hujan Jatinangor. Jurnal Kultivasi Vol. 16 (2) Agustus 2017. Department of Crop Science, Padjadjaran University.

\section{Ucapan Terima Kasih}

Tim Penulis mengucapkan banyak terima kasih kepada Dikti melalui Hibah Ristek BRIN Program PKM, Rektor Universitas Warmadewa dan Lembaga Pengabdian Kepada Masyarakat atas segala bantuannya, Aparat dan Masyarakat Desa Pancasari yang memberi kesempatan untuk melakukan kegiatan pengabdian, Anggota kelompok Wana Sari Merta yang sudah tekun mengikuti kegiatan ini dan mahasiswa yang membantu dalam kegiatan ini sehingga berjalan lancar . 